\title{
KAJIAN PENINGKATAN KAPASITAS INLET KANAL BANJIR PELANGWOT - SEDAYULAWAS DI KABUPATEN LAMONGAN
}

\author{
Galih Habsoro Sundoro ${ }^{1}$, Mohammad Bisri ${ }^{2}$, Dian Sisinggih ${ }^{2}$ \\ ${ }^{1}$ Mahasiswa Program Magister Sumber Daya Air Universitas Brawijaya, Malang \\ ${ }^{2}$ Dosen Jurusan Teknik Pengairan, Fakultas Teknik, Universitas Brawijaya, Malang \\ e-mail : galz_gunner@yahoo.com
}

\begin{abstract}
ABSTRAK : Salah satu upaya pemerintah untuk mengendalikan banjir di Bengawan Solo Hilir adalah meningkatkan kapasitas inlet Kanal Banjir Pelangwot-Sedayulawas dari $640 \mathrm{~m}^{3} / \mathrm{dt}$ menjadi sekitar $1000 \mathrm{~m}^{3} / \mathrm{dt}$ dengan memodifikasi saluran dan pintu inlet kanal banjir. Dari hasil simulasi model menggunakan program HEC-RAS 4.1.0 diketahui bahwa kemampuan reduksi banjir kanal banjir meningkat hingga 20\% dibandingkan kondisi eksisting. Pada debit banjir desain sebesar $3400 \mathrm{~m}^{3} / \mathrm{dt}$, debit banjir di Bengawan Solo Hilir tersisa sebesar $2419.14 \mathrm{~m}^{3} / \mathrm{dt}$. Dengan kapasitas rencana Bengawan Solo Hilir sebesar $2530 \mathrm{~m}^{3} / \mathrm{dt}$, maka resiko banjir dapat dihindari. Lima tahun setelah kapasitas inlet kanal banjir ditingkatkan, kondisi dasar saluran kanal banjir dari saluran inlet hingga bendung karet akan cenderung mengalami penurunan dasar saluran, sementara di bagian muara cenderung terjadi kenaikan dasar saluran akibat pengendapan sedimen.
\end{abstract}

Kata kunci : kanal banjir, kapasitas inlet, distribusi debit, perubahan elevasi dasar saluran

\begin{abstract}
One of the government's efforts to control floods in Bengawan Solo downstream is increase the capacity of Pelangwot-Sedayulawas Floodway Inlet from $640 \mathrm{~m}^{3} / \mathrm{s}$ to about $1000 \mathrm{~m}^{3} / \mathrm{s}$ by modify the floodway inlet channel and gate. From the model simulation results using HEC-RAS 4.1.0, known that the floodways flood reduction ability increased to $20 \%$ compared to the existing condition. In flood discharge design of $3400 \mathrm{~m}^{3} / \mathrm{s}$, the flood discharge at Bengawan Solo Downstream remains at $2419.14 \mathrm{~m}^{3} / \mathrm{s}$. With Bengawan Solo Downstream capacity design at 2530 $\mathrm{m}^{3} / \mathrm{s}$, then the flood risk in Bengawan Solo Downstream can be avoided. Five years after the floodway inlet capacity increased, the floodway bed chanel conditions from inlet channel to rubber dam tends to degradation, while from the rubber dam downstream to estuary tends to aggradation.
\end{abstract}

Key words : floodway, inlet capacity, discharge distribution, bed channels elevation changes

Bengawan Solo merupakan salah satu sungai yang hampir setiap tahun mengalami permasalahan banjir, terutama terjadi di wilayah hilir, khususnya di Bojonegoro, Tuban, Lamongan, dan Gresik. Bencana banjir yang terjadi tentu saja menyebabkan banyak masalah dan kerugian bagi masyarakat yang terkena dampak banjir. Berbagai upaya telah dilakukan oleh Pemerintah untuk mengendalikan aliran Bengawan Solo guna mengurangi kerugian akibat bencana banjir. Salah satu upaya yang dilakukan adalah dengan meningkatkan kapasitas inlet Kanal Banjir Pelangwot-
Sedayulawas dari $640 \mathrm{~m}^{3} / \mathrm{dt}$ menjadi 1000 $\mathrm{m}^{3} / \mathrm{dt}$.

Terkait dengan rencana tersebut, BBWS Bengawan Solo pada Tahun 2012 telah melaksanakan kajian desain melalui Uji Model Hidraulik Fisik (UMH Fisik) Sistem Pengendalian Banjir Bengawan Solo Hilir yang difokuskan pada peningkatan kapasitas Inlet Kanal Banjir Pelangwot-Sedayulawas. Dari kajian tersebut diketahui bahwa dengan memperlebar saluran inlet dari $\pm 50.00 \mathrm{~m}$ menjadi $\pm 70.50 \mathrm{~m}$ serta menambah bukaan inlet berupa ambang tetap tanpa pintu di kanan dan kiri pintu inlet eksisting dengan lebar masing- 
masing $7.50 \mathrm{~m}$ dengan elevasi puncak pelimpah berada pada elevasi $+3.00 \mathrm{~m}$ (Gambar 1), maka maka kapasitas debit yang masuk ke kanal banjir dapat ditingkatkan menjadi $978,39 \mathrm{~m}^{3} / \mathrm{dt}$ pada saat debit banjir di Bengawan Solo mencapai $3500 \mathrm{~m}^{3} / \mathrm{dt}$ (Kirno, dkk., 2012).

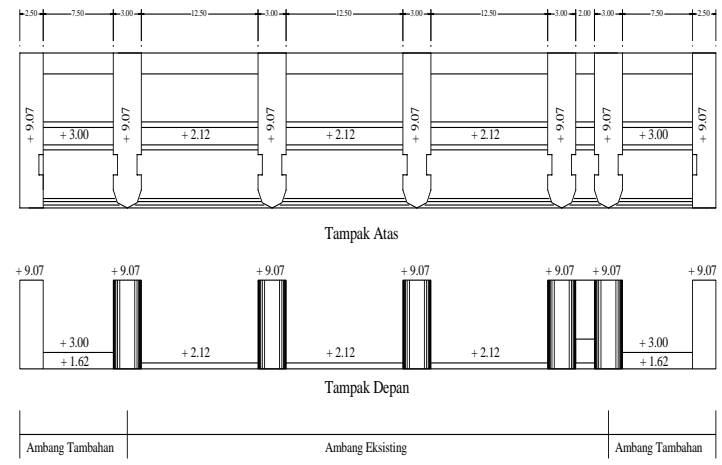

Gambar 1. Skema Modifikasi Pintu Inlet Kanal Banjir Pelangwot-Sedayulawas

Mengingat bahwa kajian yang dilakukan pada UMH Fisik hanya bersifat setempat, dimana model yang dibuat hanya meliputi daerah disekitar inlet kanal banjir, maka pengaruh peningkatan kapasitas inlet terhadap karakteristik aliran secara keseluruhan perlu dikaji lebih lanjut. Oleh karena itu kajian mengenai pengaruh peningkatan kapasitas Inlet Kanal Banjir Pelangwot - Sedayulawas perlu dilakukan untuk memberi gambaran mengenai perubahan karakteristik aliran, efektifitas reduksi banjir, serta perubahan morfologi di sepanjang kanal banjir yang mungkin terjadi.

\section{BAHAN DAN METODE}

Lokasi studi penelitian ini adalah Kanal Banjir Pelangwot-Sedayulawas membentang sepanjang kurang lebih $12,30 \mathrm{~km}$ dari Ds. Pelangwot, Kec. Laren ke arah utara sampai ke Laut Jawa di Ds. Sedayulawas, Kec. Brondong, Kab. Lamongan, Prov. Jawa Timur. Untuk lebih jelasnya dapat dilihat pada Gambar 2.

Penelitian ini dilakukan melalui simulasi Model Numerik 1 Dimensi dengan perangkat lunak HEC-RAS 4.1.0. Simulasi model dilakukan untuk menganalisa perubahan perilaku hidraulik dan angkutan sedimen setelah adanya peningkatan kapasitas inlet Kanal Banjir Pelangwot-Sedayulawas.

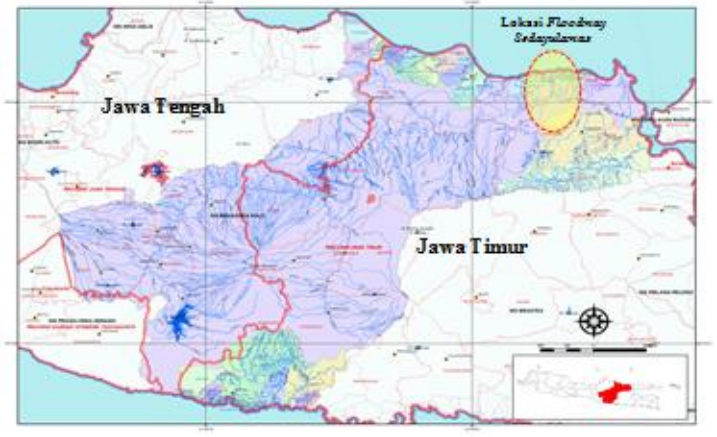

Gambar 2. Peta Lokasi Kanal Banjir Pelangwot-Sedayulawas

Data yang digunakan dalam penelitian ini berupa data sekunder dan data primer yang meliputi:

a. Data geometri perencanaan normalisasi saluran Kanal Banjir PelangwotSedayulawas dari saluran inlet s.d. bendung karet Tahun 2010;

b. Data geometri saluran Kanal Banjir Pelangwot-Sedayulawas dari inlet s.d. muara Tahun 2012;

c. Data geometri Bengawan Solo dari hilir Bendung Gerak Babat s.d. muara Tahun 2014;

d. Data teknis pintu inlet kanal banjir dan bendung karet eksisting;

e. Data teknis desain modifikasi peningkatan kapasitas inlet hasil uji model fisik Tahun 2012;

f. Data debit jam-jamam di Babat dari Tahun 2001 s.d. Tahun 2006;

g. Data debit maksimum harian di Bendung Gerak Babat dari Tahun 2007 s.d. dengan Tahun 2015;

h. Data debit jam-jaman di Bendung Gerak Babat Tahun 2015;

i. Data prediksi pasang surut jam-jaman di Pos Karang Jamuang (Alur Pelayaran Barat Surabaya) selama Tahun 2015;

j. Data pengamatan tinggi muka air jamjaman di Inlet Kanal Banjir, Pos Laren, Pos Karanggeneng, dan Pos Kuro selama Tahun 2015;

k. Data elevasi acuan pasang surut di Sedayulawas Kabupaten Lamongan dari hasil kajian Tahun 2014;

1. Data konsentrasi sedimen melayang di hulu saluran inlet Kanal Banjir PelangwotSedayulawas Tahun 2012.

m. Data sampel material dasar di Kanal Banjir Pelangwot-Sedayulawas dari pengambilan langsung dilapangan. 
Dalam penelitian ini terdapat 2 (dua) kajian utama, yaitu kajian karakteristik aliran dan kajian angkutan sedimen. Kajian karakteristik aliran dimaksudkan untuk mengetahui perubahan karakteristik aliran baik di Bengawan Solo maupun di saluran Kanal Banjir Pelangwot-Sedayu lawas setelah adanya peningkatan kapasitas inlet kanal banjir. Sedangkan kajian angkutan sedimen dilakukan untuk mengetahui prediksi perubahan elevasi dasar saluran yang mungkin terjadi 5 (lima) tahun mendatang.

Debit banjir rancangan pada penelitian ini dihitung dari data debit historis di Babat dan Bendung Gerak Babat dari Tahun 2001 sampai Tahun 2015. Debit banjir rancangan dihitung dengan Metode Log Pearson III dan diuji dengan Uji Smirnov-Kolmogorof dan Uji ChiSquare. Sedangkan hidrograf banjir pada berbagai periode ulang dibuat dengan pendekatan dari hidrograf banjir historis.

Sebelum dilakukan simulasi model, terlebih dahulu dilakukan kalibrasi dan validasi model untuk memastikan hasil simulasi cukup valid menggambarkan kondisi lapangan. Kalibrasi model dilakukan dengan mengubahubah koefisien kekasaran Manning (n) untuk memperoleh tinggi muka air hasil simulasi model yang similar dengan tinggi muka air hasil pengukuran lapangan. Validasi model dilakukan dengan uji Root Mean Square Error (RMSE) untuk mengetahui tingkat keakuratan model terhadap kondisi di lapangan pada berbagai koefisien kekasaran Manning yang digunakan.

Mengingat bahwa dalam HEC-RAS 4.1.0 terdapat berberapa persamaan angkutan sedimen dan persamaan kecepatan endap yang dapat digunakan untuk simulasi, maka sebelum dilakukan simulasi angkutan sedimen perlu dicari kombinasi persamaan yang memberikan hasil simulasi paling mendekati kondisi lapangan. Persamaan angkutan sedimen dipilih berdasarkan perubahan elevasi dasar saluran hasil simulasi yang paling sesuai dengan kondisi lapangan.

\section{HASIL DAN PEMBAHASAN Debit Banjir Rancangan}

Hasil identifikasi data debit maksimum tahunan selama Tahun 2001 sampai Tahun 2015 disajikan dalam Tabel 1. Data tersebut kemudian digunakan untuk menghitung debit banjir rancangan pada berbagai periode ulang menggunakan Metode Log Pearson III. Hasil analisa frekuensi debit banjir rancangan di Bengawan Solo Hilir disajikan dalam Tabel 2.

Tabel 1. Data Debit Maksimum Tahunan Tahun 2001 -2015

\begin{tabular}{|c|c|c|}
\hline No. & Tahun & Debit Maksimum $\left(\mathbf{m}^{3} / \mathbf{d t}\right)$ \\
\hline \hline 1 & 2001 & 1603.97 \\
\hline 2 & 2002 & 1545.48 \\
\hline 3 & 2003 & 1453.08 \\
\hline 4 & 2004 & 1489.07 \\
\hline 5 & 2005 & 1415.34 \\
\hline 6 & 2006 & 1439.01 \\
\hline 7 & 2007 & 1963.09 \\
\hline 8 & 2008 & 1961.54 \\
\hline 9 & 2009 & 2003.73 \\
\hline 10 & 2010 & 1666.62 \\
\hline 11 & 2011 & 1644.63 \\
\hline 12 & 2012 & 1617.61 \\
\hline 13 & 2013 & 1919.80 \\
\hline 14 & 2014 & 1777.68 \\
\hline 15 & 2015 & 1665.80 \\
\hline
\end{tabular}

Sumber: hasil identifikasi

Tabel 2. Data Debit Rancangan Bengawan Solo Hilir

\begin{tabular}{|c|c|c|}
\hline No. & Periode Ulang & Debit \\
\hline 1 & 1.05 & 1383.865 \\
\hline 2 & 2 & 1656.888 \\
\hline 3 & 5 & 1838.883 \\
\hline 4 & 10 & 1948.227 \\
\hline 5 & 25 & 2077.500 \\
\hline 6 & 50 & 2168.819 \\
\hline 7 & 100 & 2256.350 \\
\hline 8 & 1000 & 2533.567 \\
\hline
\end{tabular}

Sumber: hasil perhitungan

Data debit banjir historis yang digunakan untuk membuat hidrograf debit banjir rancangan adalah debit banjir di Bendung Gerak Babat pada tanggal 2 s.d. 12 April 2015 dengan puncak debit sebesar $1665.80 \mathrm{~m}^{3} / \mathrm{dt}$ (Gambar 3). Hasil konversi hidrograf debit banjir rancangan ditunjukkan pada Gambar 4.

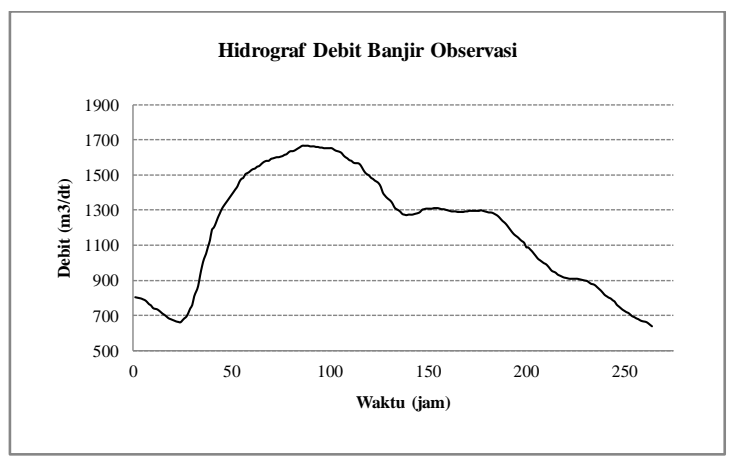

Gambar 3. Hidrograf Banjir Observasi (2 - 12 April 2015) 


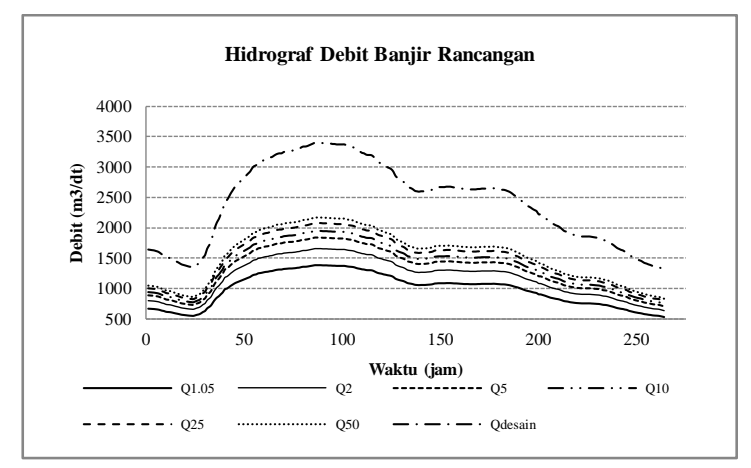

Gambar 4. Hidrograf Banjir Rancangan

\section{Kajian Karakteristik Aliran}

Sebelum dilakukan simulasi, kalibrasi model dilakukan untuk memperoleh kondisi hasil simulasi model yang similar dengan kondisi lapangan. Pada tahapan ini input data yang digunakan untuk melakukan simulasi model adalah sebagai berikut:

a. Geometri: geometri kondisi eksisting

b. Kondisi batas hulu: debit outflow Bendung Gerak Babat jam-jaman pada tanggal 2 April 2015 sampai tanggal 12 April 2015 (Gambar 3).

c. Kondisi batas hilir: prediksi elevasi muka air pasang surut jam-jaman di pada tanggal 2 April 2015 sampai tanggal 12 April 2015 (Gambar 5);

d. Kondisi model: model dasar tetap (fixedbed model) dan parameter sedimen tidak diperhitungkan;

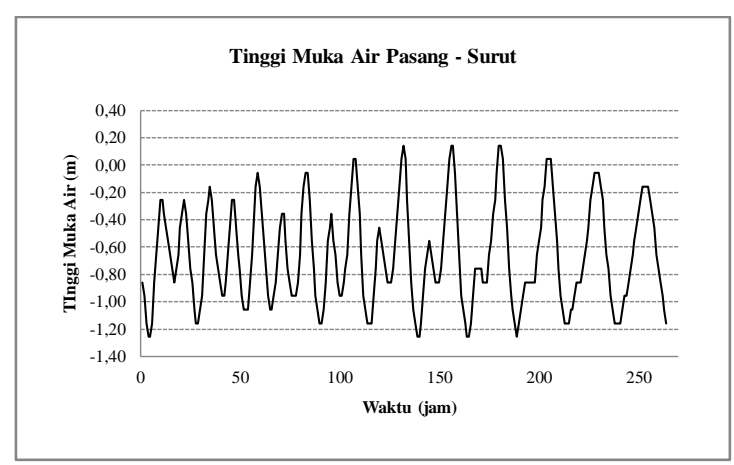

Gambar 5. Grafik Input Tinggi Muka Air Pasang-Sururt Kondisi Batas Hilir

Proses kalibrasi dilakukan dengan mengubah-ubah koefisien kekasaran Manning (n) pada model agar diperoleh tinggi muka jamjaman hasil simulasi yang similar dengan hasil pengukuran tinggi muka air jam-jaman di lapangan pada pos pemantauan tinggi muka air yang meliputi: Inlet Kanal Banjir PelangwotSedayulawas, Pos Laren, Pos Karanggeneng, dan Pos Kuro (Gambar 6). Kalibrasi dilakukan dengan empat variasi koefisien kekasaran Manning (n) seperti ditunjukkan pada Tabel 3. Hasil simulasi tinggi muka air model di ditunjukkan pada Gambar 7.

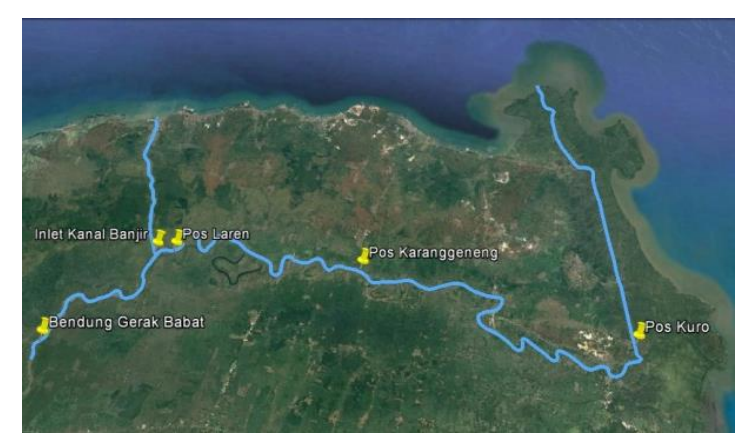

Gambar 6. Peta Lokasi Pos Pemantauan Tinggi Muka Air di Bengawan Solo Hilir

Tabel 3. Variasi Koefisien Manning Untuk Kalibrasi Model

\begin{tabular}{|c|l|c|c|}
\hline \multirow{2}{*}{ Variasi } & \multirow{2}{*}{ Jaringan Sungai } & \multicolumn{2}{|c|}{$\begin{array}{c}\text { Koefisien } \\
\text { Manning }(\boldsymbol{n})\end{array}$} \\
\cline { 3 - 4 } & $\begin{array}{c}\text { Alur } \\
\text { Utama }\end{array}$ & Bantaran \\
\hline \hline \multirow{2}{*}{ Manning 1 } & Bengawan Solo & 0.022 & 0.040 \\
\cline { 2 - 4 } & Kanal Banjir & 0.022 & 0.040 \\
\hline \multirow{2}{*}{ Manning 2 } & Bengawan Solo & 0.019 & 0.040 \\
\cline { 2 - 4 } & Kanal Banjir & 0.019 & 0.040 \\
\hline \multirow{3}{*}{ Manning 3 } & Bengawan Solo & 0.018 & 0.040 \\
\cline { 2 - 4 } & Kanal Banjir & 0.018 & 0.040 \\
\hline & $\begin{array}{l}\text { Bengawan Solo } \\
\text { STA 960 - 750 }\end{array}$ & 0.019 & 0.040 \\
\cline { 2 - 4 } & $\begin{array}{l}\text { Bengawan Solo } \\
\text { STA 740 - 310 }\end{array}$ & 0.018 & 0.040 \\
\cline { 2 - 4 } & Kanal Banjir & 0.018 & 0.040 \\
\hline
\end{tabular}

Sumber: hasil analisa

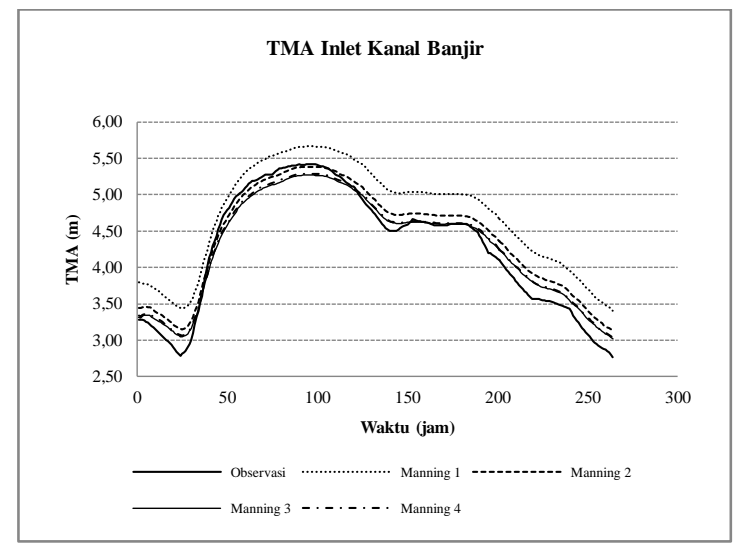

Gambar 7. Tinggi Muka Air Hasil Simulasi di Pos PA. Kanal Banjir Pada Berbagai Variasi Koefisien Manning

Dari hasil simulasi model kemudian dilakukan uji validasi terhadap hasil simulasi model dengan Uji RMSE. Uji RMSE dilakukan dengan membandingkan tinggi muka air jam- 
jaman hasil pengukuran lapangan dengan tinggi muka air jam-jaman hasil simulasi pada setiap pos pemantauan. Hasil uji RMSE ditunjukkan pada Tabel 4. Dari hasil uji RMSE diketahui bahwa model dengan variasi koefisien kekasaran Manning 4 memiliki nilai RMSE rata-rata terkecil yaitu sebesar 0.13 . Oleh karena itu, maka model dengan variasi koefisien kekasaran Manning 4 dianggap sebagai model dengan kondisi yang paling mendekati kondisi di lapangan.

Tabel 4. Rekapitulasi Hasil Uji RMSE Model

\begin{tabular}{|l|c|c|c|c|}
\hline \multirow{2}{*}{\multicolumn{1}{c|}{ Pos }} & \multicolumn{4}{|c|}{ Variasi Koefisien Manning (n) } \\
\cline { 2 - 5 } & $\mathbf{1}$ & $\mathbf{2}$ & $\mathbf{3}$ & $\mathbf{4}$ \\
\hline \hline Inlet Kanal Banjir & 0.467 & 0.207 & 0.149 & 0.149 \\
\hline Laren & 0.333 & 0.116 & 0.171 & 0.159 \\
\hline Kr. Geneng & 0.526 & 0.243 & 0.149 & 0.111 \\
\hline Kuro & 0.452 & 0.229 & 0.155 & 0.101 \\
\hline RMSE Rerata & $\mathbf{0 . 4 4 4}$ & $\mathbf{0 . 1 9 9}$ & $\mathbf{0 . 1 5 6}$ & $\mathbf{0 . 1 3 0}$ \\
\hline Sumber: hasil analisa
\end{tabular}

Setelah diperoleh model yang terkalibrasi, kemudian dilakukan simulasi pada kondisi eksisting maupun pada kondisi setelah kapasitas inlet kanal banjir ditingkatkan. Simulasi model kondisi eksisting dilakukan dengan mengganti kondisi batas hulu dan hilir dengan debit banjir rancangan pada berbagai periode ulang (Gambar 4) dan tinggi muka air pasang tertinggi (HWL) yaitu pada +0.00 untuk mensimulasikan kondisi banjir terekstrim yang mungkin terjadi. Simulasi model pada kondisi setelah adanya peningkatan kapasitas inlet kanal banjir dilakukan dengan mengganti geometri saluran inlet dan pintu inlet sesuai dengan hasil kajian UMH Fisik Tahun 2012.

Perbandingan proporsi distribusi debit banjir di inlet kanal banjir pada kondisi eksisting dan setelah adanya peningkatan kapasitas inlet kanal banjir ditunjukkan pada Tabel 5 dan Gambar 8. Perbandingan proporsi distribusi debit banjir tersebut menunjukkan bahwa dengan modifikasi yang dilakukan pada saluran dan pintu inlet, maka proporsi debit banjir yang masuk ke kanal banjir menjadi lebih besar.

Pada kondisi eksisting, kanal banjir hanya mampu mengalirkan debit banjir sebesar $19.81 \%$ hingga $23.72 \%$ dari total debit banjir di Bengawan Solo, sedangkan setelah dilakukan modifikasi debit yang masuk ke kanal banjir meningkat menjadi sebesar $22.26 \%$ hingga $28.40 \%$ dari total debit banjir yang terjadi di Bengawan Solo.
Tabel 5. Proporsi Distribusi Debit Banjir di Inlet Kanal Banjir

\begin{tabular}{|c|c|c|c|c|c|}
\hline \multirow[b]{2}{*}{ Debit } & \multirow[b]{2}{*}{ Reach } & \multicolumn{2}{|c|}{ Eksisting } & \multicolumn{2}{|c|}{ Modifikasi Inlet } \\
\hline & & $\begin{array}{l}\text { Debit } \\
\left(\mathrm{m}^{3} / \mathrm{s}\right) \\
\end{array}$ & $\%$ & $\begin{array}{l}\text { Debit } \\
\left(\mathrm{m}^{3} / \mathbf{s}\right) \\
\end{array}$ & $\%$ \\
\hline \multirow{3}{*}{$\mathrm{Q}_{1.05}$} & BS. Hulu & 1377.66 & 100.00 & 1379.59 & 100.00 \\
\hline & BS. Hilir & 1104.68 & 80.19 & 1072.46 & 77.74 \\
\hline & Kanal Banjir & 272.97 & 19.81 & 307.13 & 22.26 \\
\hline \multirow{3}{*}{$\mathrm{Q}_{2}$} & BS. Hulu & 1649.13 & 100.00 & 1651.31 & 100.00 \\
\hline & BS. Hilir & 1293.57 & 78.44 & 1244.96 & 75.39 \\
\hline & Kanal Banjir & 355.56 & 21.56 & 406.35 & 24.61 \\
\hline \multirow{3}{*}{$\mathrm{Q}_{5}$} & BS. Hulu & 1830.25 & 100.00 & 1830.74 & 100.00 \\
\hline & BS. Hilir & 1422.91 & 77.74 & 1360.11 & 74.29 \\
\hline & Kanal Banjir & 407.34 & 22.26 & 470.63 & 25.71 \\
\hline \multirow{3}{*}{$\mathrm{Q}_{10}$} & BS. Hulu & 1938.58 & 100.00 & 1939.31 & 100.00 \\
\hline & BS. Hilir & 1502.15 & 77.49 & 1432.91 & 73.89 \\
\hline & Kanal Banjir & 436.43 & 22.51 & 506.40 & 26.11 \\
\hline \multirow{3}{*}{$\mathrm{Q}_{25}$} & BS. Hulu & 2067.32 & 100.00 & 2067.85 & 100.00 \\
\hline & BS. Hilir & 1595.29 & 77.17 & 1519.48 & 73.48 \\
\hline & Kanal Banjir & 472.03 & 22.83 & 548.36 & 26.52 \\
\hline \multirow{3}{*}{$\mathrm{Q}_{50}$} & BS. Hulu & 2158.09 & 100.00 & 2158.93 & 100.00 \\
\hline & BS. Hilir & 1661.43 & 76.99 & 1580.3 & 73.20 \\
\hline & Kanal Banjir & 496.66 & 23.01 & 578.62 & 26.80 \\
\hline \multirow{3}{*}{$\mathrm{Q}_{\text {desain }}$} & BS. Hulu & 3370.51 & 100.00 & 3378.6 & 100.00 \\
\hline & BS. Hilir & 2571.17 & 76.28 & 2419.14 & 71.60 \\
\hline & Kanal Banjir & 799.34 & 23.72 & 959.47 & 28.40 \\
\hline
\end{tabular}

Sumber: hasil analisa

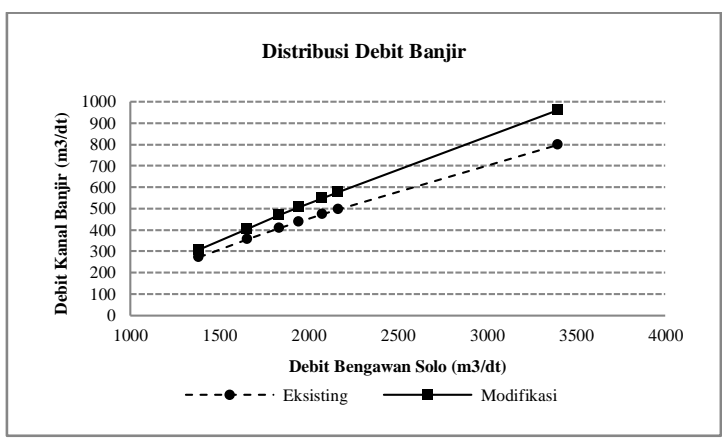

Gambar 8. Grafik Hubungan Debit Banjir Bengawan Solo Dengan Debit Kanal Banjir

Pada kondisi eksisting kanal banjir hanya mampu mengalirkan debit banjir hingga 799.34 $\mathrm{m}^{3} / \mathrm{dt}$ dan sisa debit banjir di Bengawan Solo Hilir sebesar $2571.17 \mathrm{~m}^{3} / \mathrm{dt}$, atau masih lebih besar dari kapasitas rencana Bengawan Solo Hilir sebesar $2530 \mathrm{~m}^{3} / \mathrm{dt}$ sehingga pada kondisi ini masih rawan terjadi banjir. Proporsi debit banjir yang masuk ke kanal banjir menjadi lebih besar setelah kapasitas inlet-nya ditingkatkan, yaitu hingga sebesar $959.47 \mathrm{~m}^{3} / \mathrm{dt}$ atau sekitar $20 \%$ dari kondisi eksisting. Sisa debit banjir di Bengawan Solo Hilir sebesar $2419.14 \mathrm{~m}^{3} / \mathrm{dt}$, dimana debit tersebut lebih kecil dari kapasitas rencana Bengawan Solo Hilir sebesar 2530 $\mathrm{m}^{3} / \mathrm{dt}$ sehingga resiko banjir dapat dihindari. 
Dengan adanya peningkatan debit yang masuk ke kanal banjir, kapasitas saluran kanal banjir masih mencukupi untuk menampung debit banjir hingga $959.47 \mathrm{~m}^{3} / \mathrm{dt}$ dengan tinggi jagaan tanggul (freeboard) terkecil sebesar 0.46 m. Elevasi muka air di sepanjang saluran kanal banjir hasil simulasi setelah adanya peningkatan kapasitas inlet dapat dilihat pada Gambar 11.

Pengaruh peningkatan kapasitas inlet terhadap kemampuan reduksi tinggi muka air banjir dikaji berdasarkan kriteria tinggi muka air siaga banjir pada berbagai titik pantau. Titik pantau siaga banjir yang dimaksud meliputi: Inlet Kanal Banjir Pelangwot-Sedayulawas, Pos Laren, Pos Karanggeneng, dan Pos Kuro. Adapun kriteria siaga banjir ditetapkan oleh BBWS Bengawan Solo pada tahun 2015 seperti pada Tabel 6. Tinggi muka air banjir maksimum di titik pantau pada berbagai debit banjir rancangan hasil simulasi model dapat dilihat pada Tabel 7 .

Dari hasil simulasi dapat diketahui bahwa peningkatan kapasitas inlet kanal banjir mampu menurunkan muka air banjir di Bengawan Solo Hilir, namun besarnya tidak terlalu signifikan (hanya berkisar antara $0.05 \mathrm{~m}$ hingga $0.22 \mathrm{~m}$ ). Jika mengacu pada kondisi kriteria siaga banjir saat ini, peningkatan kapasitas inlet ini tidak mampu menghilangkan resiko terjadinya banjir di Bengawan Solo Hilir pada debit banjir desain $3400 \mathrm{~m}^{3} / \mathrm{dt}$.

Namun jika kapasitas rencana Bengawan Solo Hilir sebesar $2530 \mathrm{~m}^{3} / \mathrm{dt}$ telah terpenuhi, maka dengan peningkatan kapasitas inlet Kanal Banjir Pelangwot-Sedayulawas resiko bencana banjir di Bengawan Solo Hilir akan dapat dihindari karena debit puncak banjir yang terjadi lebih kecil dari kapasitas sungai rencana (Gambar 9).

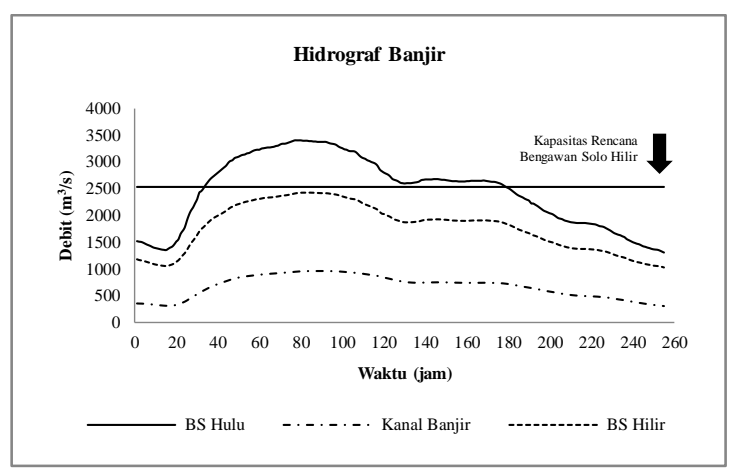

Gambar 9. Hidrograf Debit Banjir Simulasi Model Pada Debit desain $3400 \mathrm{~m}^{3} / \mathrm{dt}$ Setelah Adanya Peningkatan Kapasitas Inlet

Berubahnya distribusi debit banjir juga berpengaruh terhadap berubahnya kecepatan aliran. Dari hasil simulasi diketahui bahwa kecepatan aliran di Bengawan Solo Hulu dan saluran kanal banjir mengalami peningkatan dibandingkan dengan kondisi eksisting (Gambar 10). Semakin cepatnya aliran akan menyebabkan genangan banjir di daerah hulu akan semakin cepat surut. Sehingga dapat dikatakan peningkatan kapasitas inlet kanal banjir, selain mengurangi debit banjir yang masuk ke Bengawan Solo Hilir juga akan menurunkan tinggi muka air banjir dan lama genangan di Bengawan Solo Hulu.

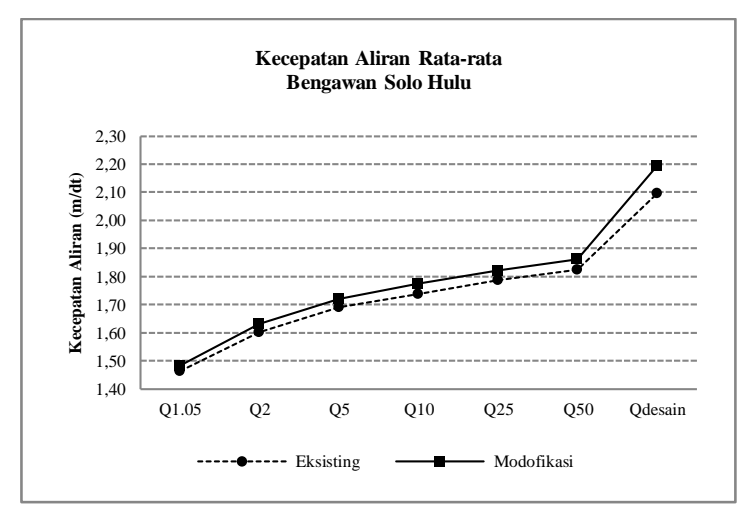

Gambar 10. Kecepatan Aliran Rata-rata di Bengawan Solo Hulu Pada Berbagai Debit Banjir Rancangan

Tabel 6. Kriteria Siaga Banjir Pada Titik Pantau Yang Tersedia Peill Schaal

\begin{tabular}{|c|c|c|c|c|}
\hline \multirow{2}{*}{ Kriteria Siaga Banjir } & \multicolumn{5}{|c|}{ Elevasi Muka Air (m) } \\
\cline { 2 - 5 } & Inlet & Laren & Kr. Geneng & Kuro \\
\hline \hline Siaga Hijau & 4.50 & 4.50 & 3.50 & 1.50 \\
\hline Siaga Kuning & 5.00 & 5.00 & 4.00 & 2.00 \\
\hline Siaga Merah & 5.50 & 5.50 & 4.50 & 2.50 \\
\hline
\end{tabular}

Sumber: $O \& P$ Perencanaan, 2015 


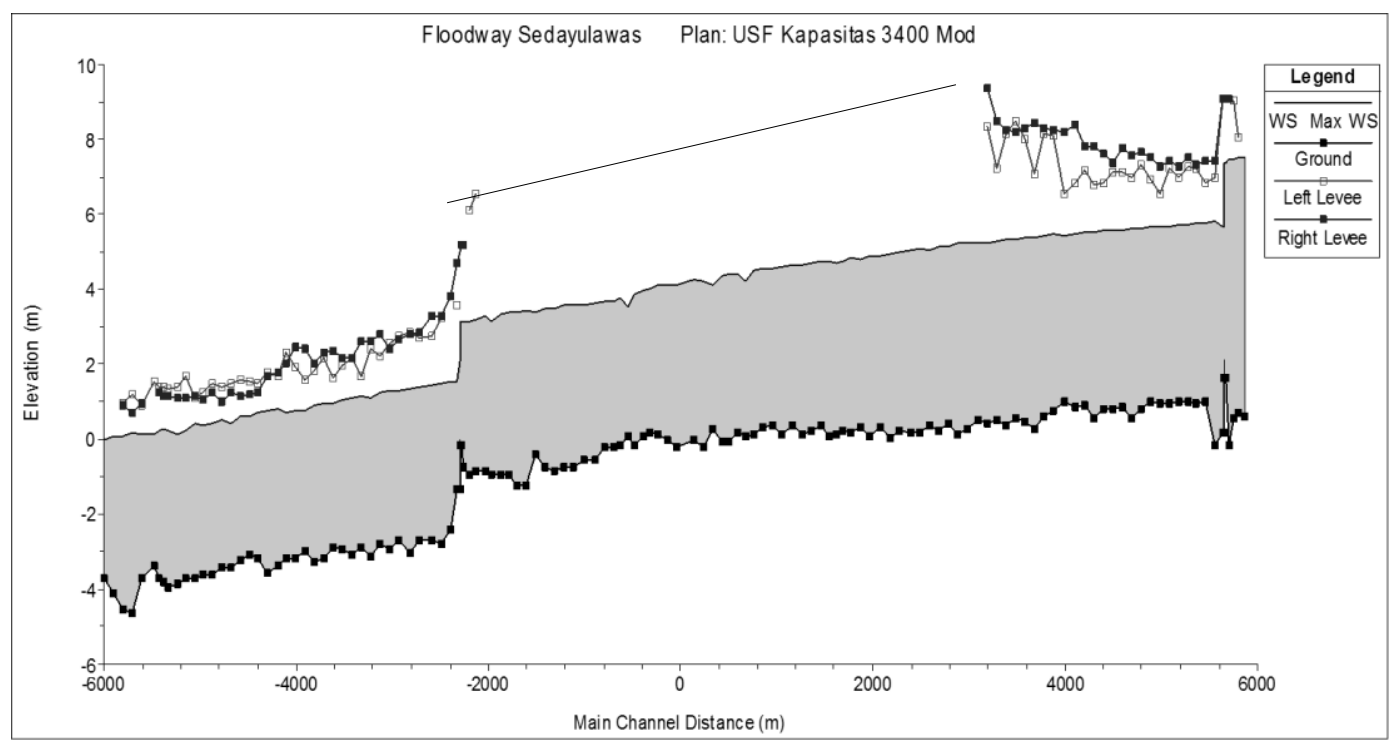

Gambar 11. Hasil Simulasi Elevasi Muka Air Maksimum Disepanjang Saluran Kanal Banjir Setelah Adanya Peningkatan Kapasitas Inlet

Tabel 7. Elevasi Mukai Air Banjir Maksimum di Titik Pantau Pada Berbagai Debit Banjir Rancangan Hasil Simulasi Model

\begin{tabular}{|c|c|c|c|c|c|c|}
\hline \multirow{2}{*}{$\begin{array}{c}\text { Debit } \\
\text { Rancangan }\end{array}$} & \multirow{2}{*}{ POS } & \multicolumn{2}{|c|}{ Eksisting } & \multicolumn{2}{|c|}{ Modifikasi Inlet } & \multirow{2}{*}{$\begin{array}{l}\text { Reduksi Muka } \\
\text { Air Banjir (m) }\end{array}$} \\
\hline & & TMA Max (m) & Ket. & TMA Max (m) & Ket. & \\
\hline \multirow{4}{*}{$\mathrm{Q}_{1.05}$} & PA. Floodway & 4.78 & $\mathrm{H}$ & 4.73 & $\mathrm{H}$ & 0.05 \\
\hline & Laren & 4.85 & $\mathrm{H}$ & 4.75 & $\mathrm{H}$ & 0.10 \\
\hline & Kr. Geneng & 3.68 & $\mathrm{H}$ & 3.59 & $\mathrm{H}$ & 0.09 \\
\hline & Kuro & 1.66 & $\mathrm{H}$ & 1.60 & $\mathrm{H}$ & 0.06 \\
\hline \multirow{4}{*}{$\mathrm{Q}_{2}$} & PA. Floodway & 5.28 & $\mathrm{~K}$ & 5.21 & $\mathrm{~K}$ & 0.07 \\
\hline & Laren & 5.38 & $\mathrm{~K}$ & 5.25 & $\mathrm{~K}$ & 0.13 \\
\hline & Kr. Geneng & 4.15 & $\mathrm{~K}$ & 4.03 & $\mathrm{~K}$ & 0.12 \\
\hline & Kuro & 1.99 & $\mathrm{H}$ & 1.90 & $\mathrm{H}$ & 0.09 \\
\hline \multirow{4}{*}{$\mathrm{Q}_{5}$} & PA. Floodway & 5.57 & M & 5.50 & M & 0.07 \\
\hline & Laren & 5.68 & M & 5.55 & $\mathrm{M}$ & 0.13 \\
\hline & Kr. Geneng & 4.44 & $\mathrm{~K}$ & 4.30 & $\mathrm{~K}$ & 0.14 \\
\hline & Kuro & 2.19 & $\mathrm{~K}$ & 2.10 & $\mathrm{~K}$ & 0.09 \\
\hline \multirow{4}{*}{$\mathrm{Q}_{10}$} & PA. Floodway & 5.73 & M & 5.65 & M & 0.08 \\
\hline & Laren & 5.85 & M & 5.70 & M & 0.15 \\
\hline & Kr. Geneng & 4.60 & M & 4.46 & $\mathrm{~K}$ & 0.14 \\
\hline & Kuro & 2.32 & $\mathrm{~K}$ & 2.21 & $\mathrm{~K}$ & 0.11 \\
\hline \multirow{4}{*}{$\mathrm{Q}_{25}$} & PA. Floodway & 5.92 & M & 5.83 & M & 0.09 \\
\hline & Laren & 6.04 & $\mathrm{~B}$ & 5.89 & M & 0.15 \\
\hline & Kr. Geneng & 4.77 & $\mathrm{M}$ & 4.63 & $\mathrm{M}$ & 0.14 \\
\hline & Kuro & 2.46 & $\mathrm{~K}$ & 2.34 & $\mathrm{~K}$ & 0.12 \\
\hline \multirow{4}{*}{$\mathrm{Q}_{50}$} & PA. Floodway & 6.05 & $\mathrm{~B}$ & 5.95 & M & 0.10 \\
\hline & Laren & 6.18 & B & 6.00 & M & 0.18 \\
\hline & Kr. Geneng & 4.88 & $\mathrm{M}$ & 4.74 & $\mathrm{M}$ & 0.14 \\
\hline & Kuro & 2.55 & M & 2.44 & $\mathrm{~K}$ & 0.11 \\
\hline \multirow{4}{*}{$\mathrm{Q}_{\text {desain }}$} & PA. Floodway & 7.48 & $\mathrm{~B}$ & 7.37 & B & 0.11 \\
\hline & Laren & 7.65 & $\mathrm{~B}$ & 7.46 & B & 0.19 \\
\hline & Kr. Geneng & 6.29 & $\mathrm{~B}$ & 6.07 & $\mathrm{~B}$ & 0.22 \\
\hline & Kuro & 3.67 & $\mathrm{~B}$ & 3.50 & $\mathrm{~B}$ & 0.17 \\
\hline
\end{tabular}

Keterangan: H (Siaga Hijau), K (Siaga Kuning), M (Siaga Merah), B (Melimpas)

Sumber: hasil analisa 


\section{Kajian Angkutan Sedimen}

Sampel material dasar dalam penelitian ini diambil langsung dilapangan pada Tahun 2016 di tiga titik pengambilan sampel seperti pada Gambar 12. Selanjutnya sampel material sedimen diuji di laboratorium makanika tanah untuk memperolah data berat jenis dan gradasi material dasar. Dari hasil pengujian di laboratorium diperoleh rerata berat jenis material dasar saluran Kanal Banjir PelangwotSedayulawas sebesar 2.916. Grafik distribusi butiran material dasar saluran Kanal Banjir Pelangwot Sedayulawas hasil pengujian laboratorium ditunjukkan pada Gambar 13.

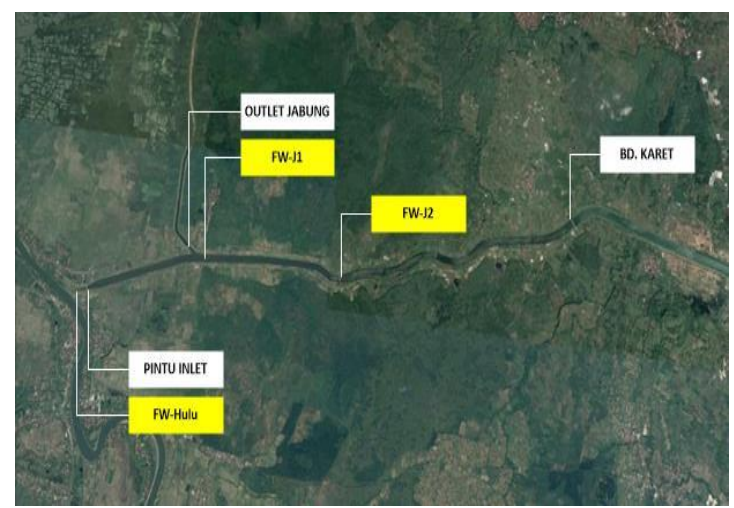

Gambar 12. Lokasi Pengambilan Sampel Material Dasar

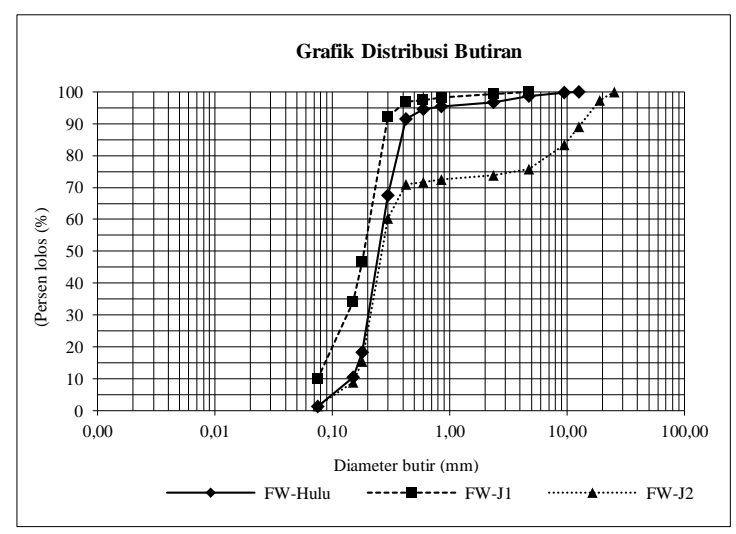

Gambar 13. Grafik Distribusi Butiran Kanal Banjir Pelangwot-Sedayulawas

Angkutan sedimen total merupakan penjumlahan dari angkutan sedimen melayang dan angkutan sedimen dasar (Van Rijn, 2013). Angkutan sedimen melayang dapat dihitung dari data konsentrasi sedimen melayang dan debit aliran saat pengambilan sampel di inlet kanal banjir hasil pengukuran Balai Sungai Tahun 2012 dengan metode USBR (United State Beurau Reclamation) dengan persamaan berikut:

$$
Q_{s}=0,0864 \cdot C \cdot Q_{w}
$$

Karena data angkutan sedimen melayang yang diperoleh hanya mewakili beberapa debit pengukuran saja, maka angkutan sedimen layang pada debit diluar hasil pengukuran dapat dihitung dengan lengkung aliran (rating-curve) sedimen yang merupakan garis regresi curva berpangkat (power curve) antara angkutan sedimen dan debit air dengan Persamaan 2 (Asdak, 2007). Rating-curve angkutan sedimen melayang hasil pengukuran lapangan ditunjukkan pada Gambar 14.

$$
Q_{s}=a \cdot Q_{w}^{b}
$$

Dengan :

$Q_{S}=$ Transpor sedimen melayang (ton/hari)

$C=$ Konsentrasi sedimen ( $\mathrm{mg} / \mathrm{lt})$

$Q_{w}=$ Debit air $\left(\mathrm{m}^{3} / \mathrm{dt}\right)$

$a, b=$ Koefisien

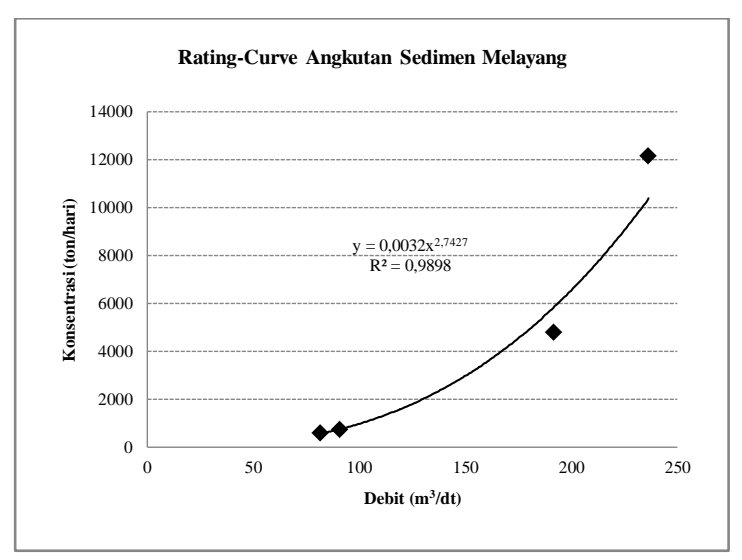

Gambar 14. Rating-curve Angkutan Sedimen Melayang

Besarnya angkutan sedimen dasar dapat diperkirakan dari data konsentrasi sedimen melayang dan jenis material dasar menggunakan Tabel 8. Dengan konsentrasi angkutan sedimen melayang kurang dari 1000 ppm dan dengan jenis material dasar saluran yang berupa pasir (sand), maka persentase angkutan sedimen dasar terhadap angkutan sedimen melayang dapat diasumsikan berada pada kisaran $25 \%$ - $150 \%$. Sebelum dilakukan simulasi model perlu dicari kombinasi persamaan yang akan memberikan hasil paling mendekati kondisi lapangan. Pemilihan persamaan angkutan sedimen dilakukan melalui kalibrasi dan validasi model. 
Tabel 8. Persentase Korelasi Angkutan Sedimen Dasar dengan Konsentrasi Sedimen Melayang

\begin{tabular}{|c|c|c|c|}
\hline $\begin{array}{c}\text { Konsentrasi Sedimen } \\
\text { Melayang (ppm) }\end{array}$ & Jenis Material Dasar Sungai & $\begin{array}{c}\text { Tekstur Sedimen } \\
\text { Melayang }\end{array}$ & $\begin{array}{c}\text { Persentase Sedimen } \\
\text { Dasar Terhadap } \\
\text { Sedimen Melayang (\%) }\end{array}$ \\
\hline \hline$<1000$ & Sand & Sama dengan material dasar & $25-150$ \\
\hline$<1000$ & $\begin{array}{c}\text { Gravel, Rock atau } \\
\text { Consolidated Clay }\end{array}$ & Terdapat sedikit sand & $5-12$ \\
\hline $1000-7500$ & Sand & Sama dengan material dasar & $10-22$ \\
\hline $1000-7500$ & $\begin{array}{c}\text { Gravel, Rock atau } \\
\text { Consolidated Clay }\end{array}$ & $25 \%$ sand atau kurang & $5-12$ \\
\hline$>7500$ & Sand & Sama dengan material dasar & $5-15$ \\
\hline$>7500$ & $\begin{array}{c}\text { Gravel, Rock atau } \\
\text { Consolidated Clay }\end{array}$ & $25 \%$ sand atau kurang & $2-8$ \\
\hline
\end{tabular}

Sumber: Bureau of Reclamation (1974)

Kalibrasi model dilakukan dengan membandingkan elevasi dasar saluran terendah hasil simulasi model angkutan sedimen pasca normalisasi Tahun 2010 hingga Tahun 2012 dengan data elevasi dasar saluran terendah hasil pengukuran penampang melintang Tahun 2012. Simulasi kalibrasi ini dilakukan dengan beberapa kombinasi persamaan angkutan sedimen (Ackers-White, England-Hansen, Laursen (Copeland), Meyer-Peter-Muller, Toffaleti, dan Yang) dengan persamaan kecepatan endap (Rubey, Toffalety, Van Rijn).

Validasi model dilakukan dengan metode uji RMSE untuk mengetahui tingkat keakuratan model terhadap kondisi di lapangan pada berbagai skenario kombinasi persamaan angkutan sedimen. Kombinasi persamaan angkutan sedimen yang menghasilkan nilai RMSE terkecil kemudian dipilih sebagai persamaan yang paling sesuai dengan kondisi di lapanganan.

Pada tahapan ini modul simulasi yang digunakan adalah quasi unsteady flow. Geometri yang digunakan untuk membangun model adalah data geometri perencanaan normalisasi tahun 2010. Kondisi batas hulu model menggunakan debit banjir rancangan $\mathrm{Q}_{2}$, sedangkan kondisi batas hilir model menggunakan muka air laut rata-rata (MSL). Persentase angkutan sedimen dasar terhadap digunakan $25 \%$.

Berdasarkan hasil simulasi model dengan berbagai kombinasi persamaan angkutan sedimen dan kecepatan endap diperoleh hasil RMSE seperti ditunjukkan pada Tabel 9. Diketahui kombinasi persamaan angkutan sedimen Ackers-White dan kecepatan endap Van Rijn menghasilkan RMSE dengan nilai terkecil.
Tabel 9. Hasil Uji RMSE Persamaan Angkutan Sedimen

\begin{tabular}{|c|c|c|}
\hline Pers. Angk. Sedimen & Pers. Kec. Endap & RMSE \\
\hline \multirow{3}{*}{ Ackers-White } & Rubey & 0.357 \\
\cline { 2 - 3 } & Toffaleti & 0.358 \\
\cline { 2 - 3 } & Van Rijn & $\mathbf{0 . 3 5 5}$ \\
\hline \multirow{3}{*}{ England-Hansen } & Rubey & 0.371 \\
\cline { 2 - 3 } & Toffaleti & 0.371 \\
\cline { 2 - 3 } & Van Rijn & 0.371 \\
\hline \multirow{3}{*}{ Laursen (Copeland) } & Rubey & 0.503 \\
\cline { 2 - 3 } & Toffaleti & 0.512 \\
\cline { 2 - 3 } & Van Rijn & 0.512 \\
\hline \multirow{3}{*}{ Meyer-Peter-Muller } & Rubey & 0.422 \\
\cline { 2 - 3 } & Toffaleti & 0.421 \\
\cline { 2 - 3 } & Van Rijn & 0.422 \\
\hline \multirow{3}{*}{ Toffaleti } & Rubey & 0.398 \\
\cline { 2 - 3 } & Toffaleti & 0.430 \\
\cline { 2 - 3 } & Van Rijn & 0.408 \\
\hline \multirow{3}{*}{ Yang } & Rubey & 0.360 \\
\cline { 2 - 3 } & Toffaleti & 0.369 \\
\cline { 2 - 3 } & Van Rijn & 0.359 \\
\hline
\end{tabular}

Sumber: hasil analisis

Tahap selanjutnya dilakukan simulasi ulang pada model dengan nilai RMSE terkecil dengan beberapa variasi persentase angkutan sedimen dasar untuk memperoleh model angkutan sedimen yang paling sesuai. Dalam tahapan ini simulasi model dilakukan dengan variasi persentase angkutan sedimen dasar sebesar 50\%, 100\%, dan $150 \%$.

Hasil uji RMSE persentase angkutan sedimen dasar untuk 25\%, 50\%, 100\%, dan $150 \%$ beturut-turut adalah $0.3545,0.3548$, 0.4309, dan 0.3563. Diketahui model dengan persamaan angkutan sedimen Ackers-White, persamaan kecepatan endap Van Rijn, dan persentase angkutan sedimen dasar sebesar 25\% memberikan nilai RMSE terkecil dan dianggap paling sesuai dengan kondisi lapangan (Gambar $15)$. 


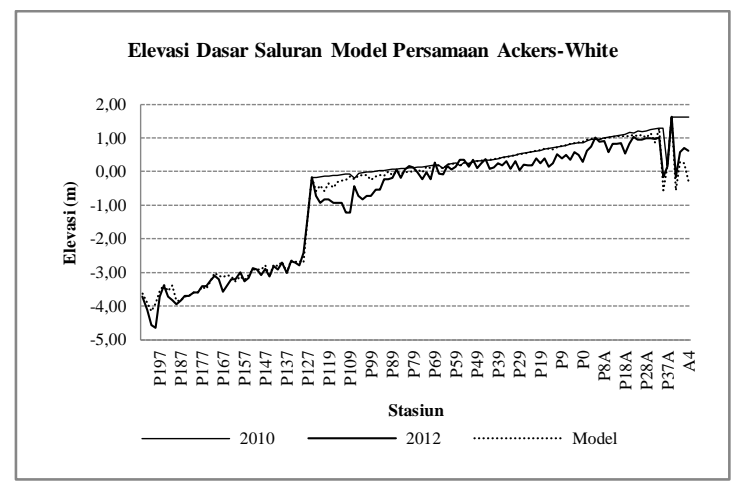

Gambar 15. Grafik Perubahan Dasar Saluran Kanal Banjir Tahun 2010-2012 Pada Model Dengan Persamaan Terpilih

Selain memiliki nilai RMSE terkecil, kombinasi persamaan ini juga menghasilkan pola perubahan dasar saluran yang sesuai dengan kondisi lapangan, yaitu terjadi gerusan di hulu dan hilir pintu inlet serta di sebelah hulu bendung karet.

\section{Prediksi Angkutan Sedimen}

Setelah diperoleh kombinasi persamaan angkutan sedimen yang sesuai dengan karakteristik angkutan sedimen di lapangan, kemudian dilakukan simulasi prediksi perubahan elevasi dasar sungai kanal banjir untuk kurun waktu 5 tahun mendatang (Tahun 2021) setelah adanya peningkatan kapasitas inlet. Pada tahapan ini model yang dibangun sama dengan data geometri eksisting dengan modifikasi saluran dan pintu inlet sesuai dengan desain perencanaan. Debit banjir rancangan $\mathrm{Q}_{2}$ dipilih sebagai input untuk kondisi batas hulu, sedangkan kondisi batas hilir model menggunakan muka air laut ratarata (MSL).

Dari hasil simulasi model diperoleh data prediksi elevasi dasar saluran kanal banjir pada 5 tahun mendatang (Tahun 2021) setelah adanya peningkatan kapasitas inlet kanal banjir (Gambar 16). Perubahan dasar saluran kanal banjir Tahun 2021 terhadap kondisi eksisting ditampilakan pada Gambar 17.

Hasil prediksi kondisi saluran kanal banjir pada Tahun 2021 menunjukkan bahwa dari saluran inlet hingga bendung karet cenderung terjadi penurunan dasar saluran (degradasi), sedangkan dari hilir bendung karet hingga ke muara cendenrung terjadi pendangkalan (agradasi). Degradasi terjadi terutama pada saluran inlet, hilir pintu inlet, serta di saluran bagian tengah antara pintu inlet dengan bendung karet.

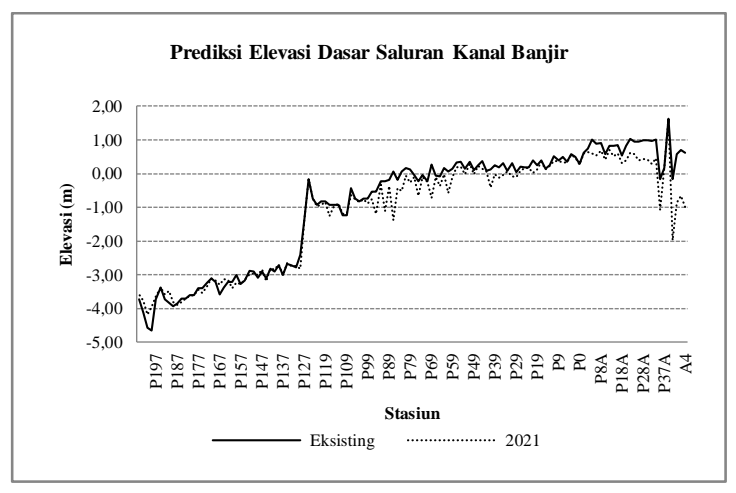

Gambar 16. Perbandingan Elevasi Dasar Saluran Kanal Banjir Tahun 2021 Kondisi Tahun 2010 dan Kondisi Eksisting

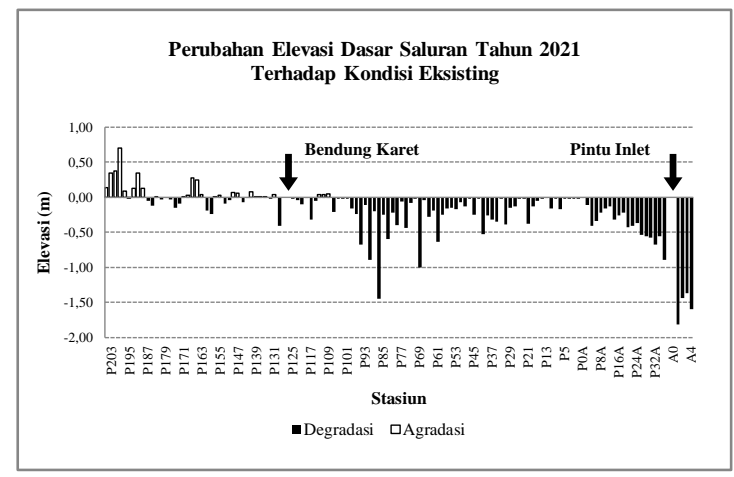

Gambar 17. Perubahan Elevasi Dasar Saluran Kanal Banjir Tahun 2021 Terhadap Kondisi Eksisting

Degradasi di saluran inlet terjadi dengan kedalaman antara $1.36-1.81 \mathrm{~m}$ dari elevasi dasar saluran eksisting dengan gerusan terdalam terjadi pada Sta. A1 yang berada tepat disebelah hulu pintu inlet. Di hilir pintu terjadi penurunan dasar saluran hingga $0.90 \mathrm{~m}$ di Sta. P36A yang berada tepat dihilir kolam penenang pintu inlet. Dari hilir pintu inlet hingga ke bendung karet cenderung terjadi degradasi dengan kedalaman rata-rata $0.24 \mathrm{~m}$ dari elevasi dasar saluran eksisting. Gerusan terdalam terjadi pada Sta. P87 dengan kedalaman $1.44 \mathrm{~m}$ dari elevasi dasar saluran eksisting. Dasar saluran di hulu bendung karet terlihat sudah tidak banyak mengalami perubahan, dimana perubahan elevasi dasar saluran yang terjadi baik degradasi maupun agradasi tidak terlalu besar (kurang dari $0.50 \mathrm{~m}$ dari elevasi dasar saluran eksisting). Pada bagian muara terjadi kenaikan dasar saluran hingga $0.70 \mathrm{~m}$ dari elevasi dasar saluran kondisi eksisting yang terjadi pada Sta. P199.

Degradasi yang terjadi di saluran Kanal Banjir Pelangwot-Sedayulawas terjadi akibat tingginya kecepatan aliran selama pengaliran, yang berkisar antara $0.97-1.98 \mathrm{~m} / \mathrm{dt}$ atau 97 - 
$198 \mathrm{~cm} / \mathrm{dt}$. Dengan diameter butiran rata-rata $\left(\mathrm{D}_{50}\right)$ di saluran kanal banjir berkisar antara $0.185-0.26 \mathrm{~mm}$, maka berdasarkan Grafik Hjulstorm memang kecenderungan yang terjadi adalah erosi atau degradasi dasar saluran (Gambar 18).

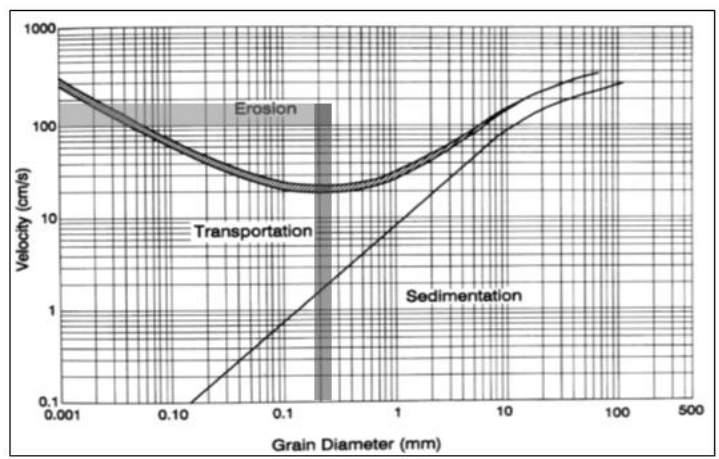

Gambar 18. Prediksi Pola Angkutan Sedimen Berdasarkan Grafik Hjulstorm

Jika elevasi dasar saluran kanal banjir Tahun 2021 dibandingkan terhadap elevasi dasar saluran pasca normalisasi (2010), maka akan memberikan nilai penurunan dasar saluran yang lebih besar. Penurunan dasar saluran atau degradasi terjadi disepanjang saluran Kanal Banjir Pelangwot-Sedayulawas mulai dari saluran inlet hingga bendung karet, seperti ditunjukkan pada Gambar 19 dan Gambar 20.

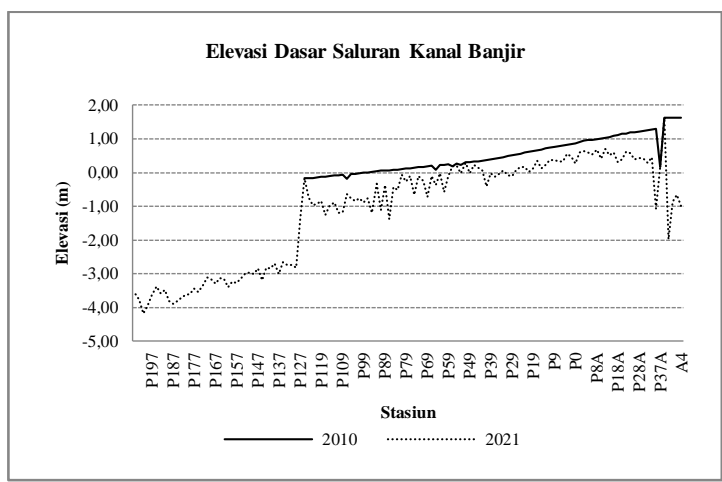

Gambar 19. Perbandingan Elevasi Dasar Saluran Kanal Banjir Tahun 2021 Terhadap Pasca Normalisasi (2010) dari Saluran Inlet Hingga Bendung Karet

Pada saluran inlet terjadi penurunan elevasi dasar saluran dengan kedalaman antara $2.28-3.59 \mathrm{~m}$ dari elevasi dasar saluran pasca normalisasi dengan penurunan terdalam terjadi di Sta. A1 yang berada tepat disebelah hulu pintu inlet. Di hilir pintu terjadi penurunan dasar saluran hingga $2.36 \mathrm{~m}$ di Sta. P36A yang berada tepat dihilir kolam penenang pintu inlet. Di sepanjang saluran kanal banjir dari hilir inlet hingga bendung karet, rata-rata penurunan elevasi dasar saluran yang terjadi adalah $0.56 \mathrm{~m}$ dari elevasi dasar saluran pasca normalisasi. Dengan menganggap bahwa elevasi dasar saluran pasca normaslisasi sebagai elevasi dasar saluran desain, maka dengan adanya penurunan elevasi dasar sungai yang cukup besar di hulu dan hilir pintu inlet akan dapat mengakibatkan ketidak-stabilan struktur pintu inlet maupun tebing saluran kanal banjir disekitarnya.

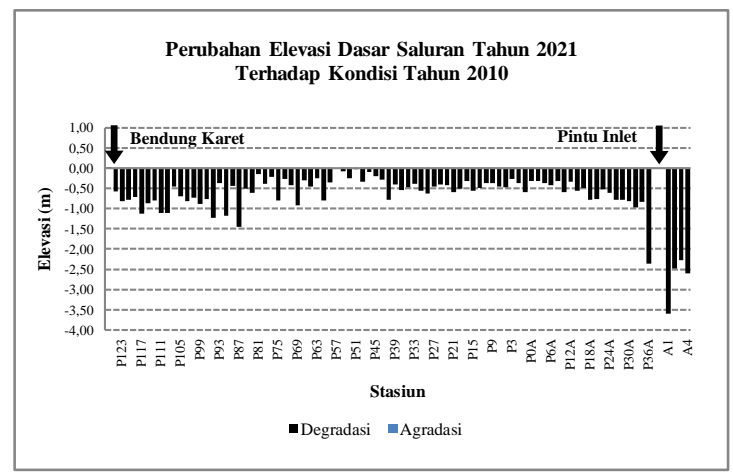

Gambar 20. Perubahan Elevasi Dasar Saluran Kanal Banjir Tahun 2021 Terhadap Kondisi Pasca Normalisasi (2010) Dari Saluran Inlet Hingga Bendung Karet

\section{KESIMPULAN}

Dari hasil kajian dapat diambil beberapa kesimpulan sebagai berikut:

1. Hasil kajian perubahan karakteristik aliran setelah adanya peningkatan kapasitas inlet kanal banjir menunjukkan hal-hal sebagai berikut:

a. Dengan adanya pelebaran saluran inlet kanal banjir menjadi $\pm 70.50 \mathrm{~m}$ dan penambahan ambang tetap tanpa pintu di kanan dan kiri pintu inlet eksisting dengan lebar masing-masing $7.50 \mathrm{~m}$, kemampuan reduksi banjir kanal banjir dapat meningkat hingga $20 \%$ dibandingkan kondisi eksisting.

b. Peningkatan kapasitas inlet kanal banjir, selain akan mengurangi debit banjir yang masuk ke Bengawan Solo Hilir juga akan menurunkan tinggi muka air banjir dan lama genangan di Bengawan Solo Hulu.

c. Pada kondisi saat ini, dimana kapasitas rencana Bengawan Solo Hilir sebesar $2530 \mathrm{~m}^{3} / \mathrm{dt}$ masih belum terpenuhi, peningkatan kapasitas inlet kanal banjir hanya akan dapat mengatasi resiko banjir di Bengawan Solo Hilir hingga 
debit banjir $\mathrm{Q}_{50}$ atau sebesar 2168.82 $\mathrm{m}^{3} / \mathrm{dt}$

d. Agar peningkatan kapasitas inlet kanal banjir dapat berfungsi sesuai rencana, untuk mengatasi debit banjir hingga $3400 \mathrm{~m}^{3} / \mathrm{dt}$, maka kapasitas rencana Bengawan Solo Hilir sebesar 2530 $\mathrm{m}^{3} / \mathrm{dt}$ juga harus terpenuhi.

2. Persamaan angkutan sedimen AckersWhite yang dikombinasikan dengan persamaan kecepatan endap Van Rijn adalah persamaan angkutan sedimen yang paling sesuai dengan karakteristik angkutan sedimen di lapangan karena menghasilkan pola perubahan dasar saluran yang similar dengan kondisi lapangan, yaitu terjadi gerusan di saluran inlet, hulu dan hilir pintu inlet, serta di hulu bendung karet.

3. Hasil simulasi prediksi perubahan dasar saluran pada Tahun 2021 menunjukkan halhal sebagai berikut:

a. Pada Tahun 2021 atau 5 tahun setelah kapasitas inlet kanal banjir ditingkatkan, kondisi dasar saluran Kanal Banjir Pelangwot-Sedayulawas dari saluran inlet hingga bendung karet akan cenderung mengalami penurunan dasar saluran (degradasi), sementara di bagian muara cenderung terjadi kenaikan dasar saluran (agradasi) akibat pengendapan sedimen;

b. Penurunan dasar saluran di saluran inlet terjadi dengan kedalaman antara 1.36 $1.81 \mathrm{~m}$ dari elevasi dasar saluran eksisting dengan penurunan dasar saluran terdalam terjadi di Sta. A1 yang berada tepat disebelah hulu pintu inlet. Di hilir pintu inlet (Sta. P36A yang berada tepat di hilir kolam penenang pintu inlet kanal banjir), penurunan dasar saluran terjadi hingga kedalaman
$0.90 \mathrm{~m}$ dari elevasi dasar saluran eksisting. Dari hilir pintu inlet hingga ke bendung karet cenderung terjadi penurunan dasar saluran dengan kedalaman rata-rata $0.24 \mathrm{~m}$ dari elevasi dasar saluran eksisting;

c. Kecenderungan terjadinya penurunan dasar saluran di sepanjang kanal banjir diakibatkan oleh tingginya kecepatan aliran, yang berkisar antara $0.59-2.34$ $\mathrm{m} / \mathrm{dt}$, sehingga material dasar saluran kanal banjir yang didominasi pasir akan cenderung tergerus dan terbawa oleh aliran.

\section{DAFTAR PUSTAKA}

Asdak, Chay. 2007. Hidrologi dan Pengelolaan Daerah Aliran Sungai. Cetakan Keempat. Yogyakarta: Gadjah Mada University Press.

Bureau of Reclamation. 1974. Design of Small Dam. Washington: Oxford \& IBH Publishing Co.

Kirno, dkk. 2012. Uji Model Hidraulik Fisik Emergency Gate Floodway Sedayu Lawas. Laporan Akhir. Tidak dipublikasikan. Surakarta: Balai Sungai.

O\&P Perencanaan. 2015. Pedoman Siaga Banjir Wilayah Sungai Bengawan Solo - Musim Hujan 2015/2016. Tidak sipublikasikan. Surakarta: Balai Besar Wilayah Sungai Bengawan Solo

Van Rijn, L. C. 2013. Simple General Formulae for Sand Transport In Rivers, Estuaries And Coastal Waters. Blokzijl: www.LEOvanRIJN-SEDIM ENT.com. http://www. leovanrijnsediment.com/papers/Formulaesandtran sport.pdf (diakses 3 Maret 2016) 